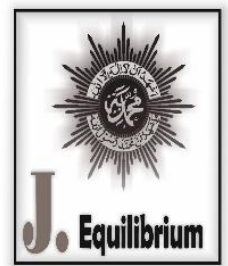

\title{
Persepsi Mahasiswa terhadap Pembelajaran Daring pada Mata Kuliah Praktik di Pendidikan Vokasi
}

\author{
Hutomo Atman Maulana ${ }^{1}$, Muhammad Hamidi ${ }^{2}$ \\ ${ }^{1}$ Administrasi Bisnis Internasional, Politeknik Negeri Bengkalis \\ Email: hutomomaulana@gmail.com \\ ${ }^{2}$ Administrasi Bisnis Internasional, Politeknik Negeri Bengkalis \\ Email: hamidisaid74@yahoo.co.id
}

\begin{abstract}
Hutomo Atman Maulana, 2020. This study aims to determine student's perceptions against online learning of the practice course at vocational education during the corona-virus pandemic (COVID-19). Student perception of online learning is limited to teaching and learning aspects, and facilities and infrastructure. This research is a qualitative descriptive study. The population in this study was all the students of the Applied Undergraduate Program Department of Internasional Business Administration of State Polytechnic of Bengkalis. The samples were taken by using purposive sampling techniques that only focused on students who were taking a practice course since enacted online learning due to the COVID-19 pandemic. The data is collected using online questionnaires and in-depth interviews with students to get more detailed information. The data analysis technique used in this study is a qualitative analysis consisting of data collection, data reduction, data presentation, and conclusion. The results showed that student's perceptions of online learning in practice course are positive, with the details of teaching and learning aspects of $66.4 \%$, the capability aspect (Lecture's proficiency) of $74.6 \%$, and the facility and infrastructure aspects of $72.7 \%$.
\end{abstract}

\section{Keywords: Student Perception, Online Learning}

Abstrak. Hutomo Atman Maulana, 2020. Penelitian ini bertujuan untuk mengetahui persepsi mahasiswa terhadap pembelajaran daring pada mata kuliah praktik di pendidikan vokasi selama masa pandemi virus corona (COVID-19). Persepsi mahasiswa terhadap pembelajaran daring dibatasi pada aspek belajar mengajar, kapabilitas (kemampuan dosen), dan sarana dan prasarana. Penelitian ini merupakan penelitian deskriptif kualitatif. Populasi pada penelitian ini adalah seluruh mahasiswa program sarjana terapan Jurusan Administrasi Niaga Politeknik Negeri Bengkalis. Sampel diambil dengan menggunakan teknik purposive sampling yang hanya berfokus pada mahasiswa yang sedang mengambil mata kuliah praktik sejak diberlakukan pembelajaran daring karena pandemi COVID-19. Data dikumpulkan dengan menggunakan kuesioner secara daring dan wawancara mendalam kepada beberapa mahasiswa untuk mendapatkan informasi yang lebih mendetail. Teknik analisis data yang digunakan dalam penelitian ini adalah analisis kualitatif yang terdiri atas pengumpulan data, reduksi data, penyajian data, dan penarikan kesimpulan. Hasil penelitian ini menunjukkan bahwa persepsi mahasiswa terhadap pembelajaran daring pada mata kuliah praktik bersifat positif, dengan rincian aspek belajar mengajar sebesar 66,4\%, aspek kapabilitas (kemampuan dosen) sebesar 74,6\%, dan aspek sarana dan prasarana sebesar 72,7\%.

Kata kunci: Persepsi Mahasiswa, Pembelajaran Daring

\section{PENDAHULUAN}

Pembelajaran dalam jaringan (daring) merupakan penerapan dari pendidikan jarak jauh secara online. Pembelajaran ini bertujuan untuk meningkatkan akses bagi peserta didik untuk memperoleh pembelajaran yang lebih baik dan bermutu. Sebab, dengan pembelajaran daring, akan memberikan kesempatan peserta didik untuk dapat mengikuti suatu pelajaran atau mata kuliah tertentu. Di masa merebaknya penyebaran virus corona (COVID-19) yang terjadi saat ini, ternyata 
menimbulkan dampak tersendiri bagi sektor pendidikan di Indonesia. Penyebaran COVID-19 yang begitu cepat menciptakan kekhawatiran bagi Pemerintah, khususnya Kementerian Pendidikan dan Kebudayaan, dan dari kalangan orang tua maupun peserta didik. Fakta inilah yang akhirnya membuat sejumlah perguruan tinggi terpaksa menghentikan sementara kegiatan belajar mengajar (KBM) secara tatap muka di dalam kelas. Hal ini jelas untuk mencegah penyebaran dan penularan COVID-19 kepada peserta didik.

Pembelajaran secara daring dianggap menjadi solusi terbaik terhadap kegiatan belajar mengajar di tengah pandemi COVID-19. Meski telah disepakati, pembelajaran ini menimbulkan kontroversi. Bagi tenaga pengajar, pembelajaran daring hanya efektif untuk penugasan, sedangkan untuk membuat peserta didik memahami materi pembelajaran secara daring dinilai sulit. Selain itu, kemampuan teknologi dan ekonomi setiap peserta didik berbeda-beda. Tidak semua peserta didik memiliki fasilitas yang menunjang kegiatan pembelajaran daring. Koneksi internet yang tidak memadai, perangkat yang tidak mendukung, dan kuota internet yang mahal menjadi penghambat pembelajaran daring. Namun, pembelajaran harus terus berlanjut. Setiap penyelenggara pendidikan memiliki kebijakan masing-masing dalam menyikapi aturan ini. Beberapa institusi pendidikan tinggi memberikan subsidi kuota internet kepada mahasiswa demi terselenggaranya pembelajaran daring.

Meski terdapat beberapa institusi pendidikan tinggi di Indonesia yang sudah siap melakukan pembelajaran daring, hadirnya COVID-19 menunjukkan institusi pendidikan tinggi yang tidak siap dalam menerapkan sistem pembelajaran daring jumlahnya lebih banyak. Misalnya, pemanfaatan teknologi pembelajaran daring masih didominasi oleh universitas di kota besar karena kapasitas finansial dan ketersediaan sistem pembelajaran digital (e-learning) yang lebih baik dibandingkan kampus kecil di daerah rural. Selain itu, tidak sedikit jumlah pendidik yang masih kesulitan menggunakan teknologi pembelajaran daring baik itu menggunakan e-learning atau pun platform lain dari pihak ketiga seperti Zoom, Google Classroom, dan CloudX. Hal ini membuat pembelajaran daring berlangsung hanya memberikan tugas secara jarak jauh tanpa ada umpan balik maupun interaksi dengan peserta didik.

Beberapa penelitian telah dilakukan terkait dengan pembelajaran daring. Tantri (2018) melakukan penelitian terhadap kehadiran sosial dalam pembelajaran daring berdasarkan sudut pandang pembelajar pendidikan terbuka dan jarak jauh. Hasil penelitian menunjukkan bahwa pembelajaran daring memiliki dampak positif terhadap apek keterhubungan, aspek pembelajaran, dan aspek sosial (socio-emotional). Khusniyah dan Hakim (2019) melakukan penelitian terhadap efektivitas pembelajaran berbasis daring dengan memanfaatkan penggunaan web blog terhadap kemampuan mahasiswa dalam memahami teks berbahasa Inggris. Hasil penelitian menunjukkan bahwa adanya perbedaan kemampuan pemahaman mahasiswa. Selain itu, pembelajaran daring dengan web blog tersebut memberikan pengaruh positif terhadap peningkatan kemampuan membaca bahasa Inggris mahasiswa. Kuntarto (2017) melakukan penelitian terhadap keefektifan model pembelajaran daring dalam perkuliahan bahasa Indonesia dengan menggunakan teknik Online Interactive Learning Model (OILM). Hasil penelitian menunjukkan model pembelajaran ini mampu meningkatkan penyerapan materi kuliah oleh mahasiswa dengan peningkatan mencapai lebih dari 81\%. Sofyana dan Rozaq (2019) melakukan penelitian terhadap pembelajaran daring kombinasi berbasis Whasapp pada kelas karyawan program studi teknik informatika. Hasil penelitian menunjukkan bahwa pembelajaran daring meningkatkan minat mahasiswa sebesar $89 \%$ dan memiliki efektivitas sebesar 78\%. Rusdiana dan Nugroho (2020) melalukan penelitian terhadap respon mahasiswa pada pembelajaran daring mata kuliah pengantar hukum Indonesia dengan menggunakan e-learning VINESA UNESA. Hasil penelitian menunjukkan bahwa motivasi mahasiswa saat mengikuti perkuliahan daring sebesar $71 \%$ dan efektivitas perkuliahan sebesar $76,4 \%$. Mustofa, dkk. (2019) melakukan penelitian terhadap formulasi model perkuliahan daring dengan memanfaatkan situs resmi pemerintah sebagai upaya menekan disparitas kualitas perguruan tinggi. Hasil penelitian menunjukkan bahwa sistem kuliah daring memiliki kontribusi positif untuk mendorong disparitas kualitas perguruan tinggi di Indonesia. 
Penelitian terdahulu semuanya dilakukan pada mata kuliah teori di institusi pendidikan tinggi umum, sedangkan masih sangat sulit ditemukan penelitian terkait pembelajaran daring pada pendidikan vokasi. Pendidikan vokasi berorientasi pada keterampilan/kecakapan kerja sesuai dengan perkembangan ilmu pengetahuan dan teknologi terapan sesuai dengan tuntutan kebutuhan lapangan kerja. Secara khusus, program pendidikan vokasi diarahkan untuk menghasilkan lulusan yang menguasai kemampuan dalam bidang kerja tertentu sehingga dapat langsung diserap sebagai tenaga kerja di industri/swasta, lembaga pemerintah atau berwirausaha secara mandiri. Oleh karena itu beban pengajaran pada program pendidikan vokasi disusun dengan lebih mengutamakan beban mata kuliah praktik/ketrampilan dibandingkan dengan beban mata kuliah teori. Maka dari itu penelitian ini bertujuan untuk mengetahui persepsi mahasiswa terhadap pembelajaran daring pada mata kuliah praktik di pendidikan vokasi pada masa pandemi COVID-19.

\section{METODE PENELITIAN}

Penelitian ini merupakan penelitian deskriptif kualitatif. Populasi pada penelitian ini adalah seluruh mahasiswa program sarjana terapan Jurusan Administrasi Niaga Politeknik Negeri Bengkalis. Sampel diambil dengan menggunakan teknik purposive sampling yang hanya berfokus pada mahasiswa yang sedang mengambil mata kuliah praktik sejak diberlakukan pembelajaran daring karena pandemi COVID-19. Data penelitian diperoleh dengan menggunakan kuesioner yang diisi secara daring oleh mahasiswa dengan menggunakan Google Form. Kuesioner yang digunakan mengadaptasi kuesioner kepuasan pelayanan mata kuliah praktik yang dikeluarkan oleh Pusat Pengembangan Pembelajaran dan Penjaminan Mutu Pendidikan (P4MP) Politeknik Negeri Bengkalis. Selain itu juga digunakan wawancara mendalam kepada beberapa mahasiswa untuk mendapatkan informasi yang lebih mendetail. Teknik analisis data yang digunakan dalam penelitian ini adalah analisis kualitatif yang terdiri atas pengumpulan data, reduksi data, penyajian data, dan penarikan kesimpulan. Tingkat persepsi mahasiswa dalam penelitian ini mengacu pada standar pengukuran yaitu: Negatif jika persentase rerata total butir komponen $\leq 40 \%$, dan positif jika persentase rerata total butir komponen $>40 \%$.

\section{HASIL DAN PEMBAHASAN}

Kuesioner diisi secara daring oleh mahasiswa jurusan administrasi niaga dari program studi sarjana terapan administrasi bisnis internasional (ABI) semester II dan semester IV dan Program studi sarjana terapan akuntansi keuangan publik (AKP) semester II dengan total responden sebanyak 180 orang. Mahasiswa jurusan administrasi niaga dipilih karena perangkat/ alat yang dibutuhkan untuk mata kuliah praktik hanya berupa perangkat komputer, sehingga sangat memungkinkan untuk dilaksanakannya pembelajaran daring. Deskripsi responden dapat dilihat pada Tabel 1.

Tabel 1

\begin{tabular}{|c|c|c|c|c|c|c|c|}
\hline \multicolumn{8}{|c|}{ Jumlah Responden } \\
\hline \multirow{3}{*}{ Kelas } & $\begin{array}{c}A B \mid 2 A \\
(\%)\end{array}$ & $\begin{array}{c}A B \mid 2 B \\
(\%)\end{array}$ & $\begin{array}{c}A B \mid 4 A \\
(\%)\end{array}$ & $\begin{array}{c}A B \mid 4 B \\
(\%)\end{array}$ & $\begin{array}{c}\text { AKP 2A } \\
(\%)\end{array}$ & $\begin{array}{c}\text { AKP 2B } \\
(\%)\end{array}$ & $\begin{array}{c}\text { Total } \\
(\%)\end{array}$ \\
\hline & 31 & 30 & 30 & 31 & 28 & 30 & 180 \\
\hline & $(17)$ & (17) & $(17)$ & $(17)$ & $(16)$ & $(17)$ & $(100)$ \\
\hline \multirow{2}{*}{$\begin{array}{l}\text { Jenis } \\
\text { kelamin }\end{array}$} & & $\begin{array}{c}\text { Laki-laki } \\
(\%)\end{array}$ & & & $\begin{array}{c}\text { Perempuan } \\
(\%)\end{array}$ & & $\begin{array}{c}\text { Total } \\
(\%)\end{array}$ \\
\hline & & $\begin{array}{l}16 \\
(9)\end{array}$ & & & $\begin{array}{l}164 \\
(91)\end{array}$ & & $\begin{array}{c}180 \\
(100)\end{array}$ \\
\hline
\end{tabular}

Sumber: Data olahan, 2020 
Kuesioner terdiri atas tiga bagian yaitu proses belajar mengajar, kapabilitas (kompetensi dosen), dan sarana dan prasarana dengan total 13 butir pertanyaan. Setiap butir pertanyaan menggunakan skala likert, yaitu: Sangat Tidak Setuju/STS (1), Tidak Setuju/TS (2), Biasa Saja/BS (3), Setuju/S (4), dan Sangat Setuju/ST (5). Hasil kuesioner dapat dilihat pada Tabel 2.

Tabel 2 Hasil Pengisian Kuesioner oleh Responden

\begin{tabular}{|c|c|c|c|c|c|c|c|c|c|c|c|}
\hline \multirow{2}{*}{ No. } & \multirow{2}{*}{ Item } & \multicolumn{2}{|c|}{ STS } & \multicolumn{2}{|c|}{ TS } & \multicolumn{2}{|c|}{ BS } & \multicolumn{2}{|c|}{$S$} & \multicolumn{2}{|c|}{ SS } \\
\hline & & $f$ & $(\%)$ & $\mathrm{f}$ & $(\%)$ & $\mathrm{f}$ & $(\%)$ & f & $(\%)$ & $\mathrm{f}$ & $(\%)$ \\
\hline & A. PROSES BELAJAR MENGAJAR & & & & & & & & & & \\
\hline 1 & $\begin{array}{l}\text { Pelaksanaan Perkuliahan daring dapat } \\
\text { diakses secara mudah }\end{array}$ & 10 & (6) & 36 & (20) & 72 & (40) & 42 & (23) & 20 & (11) \\
\hline 2 & $\begin{array}{l}\text { Pelaksanaan Perkuliahan daring tepat } \\
\text { waktu dan sesuai dengan jadwal }\end{array}$ & 8 & (4) & 20 & (11) & 68 & $(38)$ & 51 & $(28)$ & 33 & (8) \\
\hline 3 & $\begin{array}{l}\text { Perkuliahan secara daring menambah } \\
\text { pemahaman teori dan keterampilan }\end{array}$ & 25 & (14) & 55 & (31) & 56 & (31) & 32 & (18) & 12 & (7) \\
\hline 4 & $\begin{array}{l}\text { Materi yang disajikan secara daring } \\
\text { sesuai dengan Kontrak } \\
\text { Perkuliahan/RPS }\end{array}$ & 4 & $(2)$ & 9 & (5) & 48 & (27) & 60 & (33) & 59 & (33) \\
\hline \multirow[t]{2}{*}{5} & $\begin{array}{l}\text { Kemudahan dalam mengirimkan } \\
\text { tugas/laporan praktikum }\end{array}$ & 10 & (6) & 24 & (13) & 63 & (35) & 52 & (29) & 31 & (17) \\
\hline & B. KAPABILITAS (KOMPETENSI DOSEN) & & & & & & & & & & \\
\hline 6 & $\begin{array}{l}\text { Dosen selalu menemani ketika } \\
\text { pembelajaran secara daring hingga } \\
\text { selesai }\end{array}$ & 7 & (4) & 22 & (12) & 53 & (29) & 58 & $(32)$ & 40 & (22) \\
\hline 7 & $\begin{array}{l}\text { Dosen menjelaskan arah dan tujuan } \\
\text { dalam setiap pembelajaran secara } \\
\text { daring }\end{array}$ & 7 & (4) & 18 & (10) & 48 & $(27)$ & 63 & (35) & 44 & (24) \\
\hline 8 & $\begin{array}{l}\text { Dosen memberikan kesempatan } \\
\text { mahasiswa untuk bertanya dan } \\
\text { berdiskusi }\end{array}$ & 3 & $(2)$ & 5 & (3) & 31 & (17) & 73 & (41) & 68 & (38) \\
\hline 9 & $\begin{array}{l}\text { Dosen memberikan respon terhadap } \\
\text { pertanyaan yang muncul selama } \\
\text { perkuliahan secara daring }\end{array}$ & 4 & $(2)$ & 2 & (1) & 47 & (26) & 63 & (35) & 64 & (36) \\
\hline 10 & $\begin{array}{l}\text { Tingkat pemahaman anda secara } \\
\text { umum terhadap mata kuliah yang } \\
\text { disajikan secara daring }\end{array}$ & 8 & (4) & 27 & (15) & 78 & (43) & 56 & (31) & 11 & (6) \\
\hline \multirow[t]{2}{*}{11} & $\begin{array}{l}\text { Rerata keaktifan dan attitude anda } \\
\text { selama perkuliahan secara daring }\end{array}$ & 2 & (1) & 11 & (6) & 42 & (23) & 84 & (47) & 41 & (23) \\
\hline & C. SARANA DAN PRASARANA & & & & & & & & & & \\
\hline 12 & $\begin{array}{l}\text { Materi pada pembelajaran daring } \\
\text { tersedia dengan Baik }\end{array}$ & 6 & (3) & 13 & (7) & 42 & (24) & 71 & (39) & 48 & (27) \\
\hline 13 & $\begin{array}{l}\text { Saya memiliki perangkat/peralatan } \\
\text { untuk melakukan praktikum di rumah } \\
\text { sesuai dengan petunjuk yang diberikan }\end{array}$ & 14 & (8) & 24 & (13) & 43 & (24) & 59 & (33) & 40 & (22) \\
\hline
\end{tabular}

\section{Aspek Proses Belajar mengajar}

Kegiatan belajar mengajar ditandai dengan satu penggarapan materi yang khusus. Oleh karena itu materi harus didesain sedemikian rupa sehingga cocok untuk mencapai tujuan pembelajaran (Inah, 2015). Berdasarkan hasil kuesioner yang telah diisi oleh mahasiswa, dapat diketahui bahwa pelaksanaan perkuliahan daring dapat diakses oleh mahasiswa secara biasa sebesar $74 \%$, sedangkan $20 \%$ mahasiswa mengalami kesulitan dan terdapat $6 \%$ mahasiswa yang sangat sulit untuk mengakses pembelajaran secara daring. Hasil wawancara menunjukkan bahwa penyebab mahasiswa kesulitan mengakses pembelajaran daring a, yaitu: (1) kondisi jaringan yang tidak stabil atau tidak memadai, (2) gadget/perangkat yang tidak kompatibel dengan aplikasi pembelajaran 
daring, dan (3) kuota internet yang terbatas. Hal ini berdasarkan pernyataan mahasiswa_31 yang mengatakan bahwa:

"Hilang timbulnya jaringan dan kuota internet yang menjadi gangguan dalam kuliah daring".

Selain itu mahasiswa_6 juga mengatakan bahwa:

"Bagi saya kendala jaringan, gadget yang tidak mendukung dan lain sebagainya membuat pembelajaran secara daring tidak efektif layaknya face to face dikampus. Apalagi saya menjadi kurang memahami materi karena tidak ada penjelasan materi langsung dari dosen yang bersangkutan. Saya pribadi berharap semoga perkuliahan bisa kembali normal dengan sistem face-to-face, dan semoga wabah Covid-19 cepat berlalu. Aamiin".

Salah satu upaya yang dilakukan pemerintah dalam mengatasi kuota internet yang terbatas adalah dengan memberikan paket internet untuk aplikasi CloudX sebesar 30GB yang disediakan oleh operator Telkomsel dengan harga Rp.10,-. Namun, tidak semua dosen menggunakan aplikasi ini dalam melaksanakan pembelajaran daring. Hal ini sejalan dengan pernyataan mahasiswa_41 yang mengatakan bahwa:

"Cuman ada beberapa kesulitan bagi kami untuk daring selama ini, jaringan yang susah,jadi sering terhambat dalam mengikuti daring, dan untuk kemudahan paket cloudx 30gb hanya Rp.10 itu tidak bisa di gunakan sama sekali".

Dari segi ketepatan waktu perkuliahan, terdapat 15\% mahasiswa berpendapat ada pembelajaran daring yang dilaksanakan tidak sesuai dengan jadwal yang telah ditetapkan. Hasil wawancara dengan mahasiswa_46 mengatakan bahwa:

"Diharapkan dosen dan mahasiswa dapat hadir tepat waktu. dan ketika tidak ada jadwal kuliah jangan ada jadwal yang tidak sesuai jadwal yang diberikan oleh Kampus. apalagi ketika tanggal merah. dikarenakan mahasiswa sudah banyak yang pulang kampung dan memiliki kegiatan lain".

Dari segi pemahaman teori dan keterampilan, terdapat $45 \%$ mahasiswa yang mengalami kesulitan memahami materi praktikum yang dilakukan pada pembelajaran daring. Mahasiswa_111 mengatakan bahwa:

"Secara daring, ada beberapa mata kuliah yang saya tidak paham dan sulit untuk memahaminya. Dikarenakan tidak dijelaskan, kita hanya disuruh memahaminya. Dan saya berharap dosen-dosen jika menjelaskan yang mata kuliah sulit harap memakai zoom, dan bisa mengaplikasikan zoom dengan baik, misalnya menampilkan powerpoint pembelajaran di zoom. Kemudian teman-teman juga kalau dosen menjelaskan, audionya harusnya di unmute, agar terdengar jelas. Sehingga kalau di mute, saya hanya melihat dosen menjelaskan tetapi tidak paham akan penjelasannya. Sekian. Terima kasih pak sudah memberi saya waktu untuk menyampaikan apa yang saya rasakan selama daring ini". 
Selain itu juga Mahasiswa_44 mengatakan bahwa :

"Pembelajaran yang dilakukan secara daring sudah baik, namun dari saya pribadi terkadang agak sulit memahami beberapa hal di handout yang biasanya bisa dijelaskan melalui tatap muka. Terutama mata kuliah praktikum, jadi butuh waktu yang lebih banyak untuk bisa memahami sendiri. Tidak bisa berdiskusi secara bebas karena secara daring agak terbatas. Dan terkadang gangguan terhadap jaringan yang terjadi karena hal-hal tertentu, seperti salah satunya pemadaman listrik".

Dari segi kesesuaian antara materi yang disajikan dengan kontrak perkuliahan atau rencana pembelajaran semester (RPS), terdapat $7 \%$ mahasiswa yang menyatakan bahwa materi yang diberikan tidak sesuai. Hal ini menunjukkan bahwa walaupun pembelajaran dilaksanakan secara daring, Dosen pengampu mata kuliah masih tetap melaksanakan perkuliahan sesuai dengan RPS yang telah disampaikan pada pertemuan pertama. Dari segi kemudahan mengirimkan tugas atau laporan praktikum, terdapat $19 \%$ mahasiswa yang mengalami kesulitan dalam mengirimkan tugas melalui pembelajaran secara daring. Terkait hal ini, mahasiswa_141 mengatakan bahwa:

"Dalam perkuliahan daring, saat pengumpulan tugas, lewat deadline waktunya tetap bisa dikumpulkan dan diterima, karena kadangkala jaringan tidak memadai, apalagi bagi rumah yang jauh dari koneksi internet. Tolong dipermudahkan atau dikonfirmasi kepada mahasiswa untuk tugas yang sudah masuk atau belum. Karena seringkali tugas sudah dikirim, tapi belum masuk atau belum diterima dosen, karena gangguan bisa saja terjadi".

Secara keseluruhan aspek belajar mengajar mendapatkan persentase rerata sebesar $66,4 \%$ sehingga dapat dikategorikan persepsi mahasiswa terhadap aspek belajar mengajar pada pembelajaran daring untuk mata kuliah praktik adalah positif.

\section{Aspek Kapabilitas (Kemampuan Dosen)}

Dosen merupakan kunci dalam setiap upaya peningkatan mutu, relevansi, dan efisiensi pendidikan. Hal ini menuntut dosen harus mampu mempersiapkan kompetensi dirinya secara optimal (Kadir, 2018). Kemampuan dosen dalam melaksanakan perannya sebagai fasilitator adalah menyediakan kemudahan-kemudahan bagi mahasiswa dalam proses belajar mengajar, membimbing peserta didik yang mengalami kesulitan selama proses belajar mengajar, dan memberikan contoh yang baik kepada mahasiswa (Suyanto dan Jihad, 2013). Berdasarkan hasil kuesioner yang telah diisi oleh mahasiswa, dapat diketahui bahwa $83 \%$ mahasiswa menyatakan dosen selalu menemani ketika pembelajaran daring hingga selesai, $86 \%$ mahasiswa menyatakan dosen menjelaskan arah dan tujuan dalam setiap pembelajaran daring, 95\% mahasiswa menyatakan dosen memberikan kesempatan mahasiswa untuk bertanya dan berdiskusi secara daring, 97\% mahasiswa menyatakan bahwa dosen memberikan respon terhadap pertanyaan yang muncul selama pembelajaran daring, dan 93\% mahasiswa menyatakan terlibat aktif selama pembelajaran daring. Namun, masih terdapat 19\% mahasiswa masih mengalami kesulitan jika ditinjau dari tingkat pemahaman secara umum terhadap mata kuliah yang disajikan secara daring. Mahasiswa_113 mengatakan bahwa:

"Jujur saya sendiri sangat sulit untuk melakukan pembelajaran secara daring karena kurangnya memahami dan juga kadang ada bagian yang sulit untuk dikerjakan ada beberapa tugas yang bisa kita buat yang faham okelah tapi ada juga beberapa tugas yang memang saya tidak memahami karena saya sangat sulit memahami secara daring. Saya lebih mudah 
bertatap muka dan juga kadang kesulitan dalam paket kadang jaringan di sini ada yang bagus Alhamdulillah kadang ga bagus itu yang buat susah alhasil pergi ke tempat atau ke rumah teman".

Secara keseluruhan aspek kapabilitas (kemampuan dosen) mendapatkan persentase rerata sebesar $74,6 \%$ sehingga dapat dikategorikan persepsi mahasiswa terhadap aspek kapabilitas (kemampuan dosen) pada pembelajaran daring untuk mata kuliah praktik adalah positif.

\section{Aspek Sarana dan Prasarana}

Sarana dan prasarana pendidikan merupakan salah satu sumber daya yang penting dalam menunjang proses pembelajaran agar pencapaian tujuan pembelajaran dapat berjalan dengan lancar (Novita, 2017). Berdasarkan hasil kuesioner yang telah diisi oleh mahasiswa, dapat diketahui bahwa 90\% mahasiswa menyatakan bahwa materi pembelajaran daring tersedia dengan baik. Sedangkan dari aspek perangkat/peralatan, 21\% mahasiswa menyatakan bahwa tidak memiliki perangkat/peralatan untuk melakukan praktikum di rumah sesuai dengan petunjuk yang diberikan. Berdasarkan hasil wawancara diperoleh bahwa permasalahan terletak pada perangkat yang dimiliki oleh mahasiswa tidak kompatibel untuk mengakses pembelajaran daring sehingga sulit untuk melalukan praktikum di rumah. Hal ini sebagaimana disampaikan Mahasiswa_101 yang mengatakan bahwa:

"Semoga situasi ini segera membaik, dan sampai saat ini pembelajaran daring baik-baik saja. Namun dimohon kepada dosen matkul agar bisa memahami kendala-kendala yang dihadapi mahasiswa, terkait jaringan dan handphone yang masih versi lama".

Selain itu juga mahasiswa_108 mengatakan bahwa:

"Saya harap dosen tidak membebani mahasiswa dengan menggunakan aplikasi yang sulit untuk perkuliahan daring seperti cloudx atau zoom. Karena tidak semua mahasiswa mempunyai HP canggih yang bisa digunakan untuk menyimpan aplikasi tersebut. Dan tidak semua mahasiswa mempunyai laptop, seperti laptop saya saja sedang rusak dan saat harus meminjam untuk mengerjakan tugas akhir-akhir ini".

Secara keseluruhan aspek sarana dan prasarana mendapatkan persentase rerata sebesar $72,7 \%$ sehingga dapat dikategorikan persepsi mahasiswa terhadap aspek sarana dan prasarana pada pembelajaran daring untuk mata kuliah praktik adalah positif.

\section{KESIMPULAN}

Pembelajaran daring merupakan salah satu solusi pembelajaran di tengah merebaknya pandemi COVID-19. Tidak hanya terbatas pada pendidikan tinggi, pendidikan vokasi pun yang lebih mengutamakan beban mata kuliah praktik/ketrampilan dapat melaksanakan pembelajaran daring. Hal ini terlihat dari persepsi positif mahasiswa terhadap pembelajaran daring berdasarkan aspek belajar mengajar, kapabilitas (kemampuan dosen), dan sarana dan prasarana. Namun demikian, pembelajaran daring masih terkendala oleh akses internet yang masih terbatas khususnya di daerah rural, dan kondisi ekonomi mahasiswa yang terbatas sehingga tidak memiliki perangkat yang memadai untuk mengakses aplikasi pada pembelajaran daring. Saran untuk penelitian lebih lanjut agar berfokus pada efektivitas pembelajaran daring terhadap hasil belajar mahasiswa. 


\section{DAFTAR PUSTAKA}

Inah, E. N. (2015). Peran Komunikasi dalam Interaksi Guru dan Siswa. Jurnal Al-Ta'dib, 8(2), 150167.

Kadir, A. (2018). Pengaruh Kompetensi Dosen dan Motivasi Belajar Terhadap Kemampuan Analisis Statistika Mahasiswa FTIK IAIN Kendari. Al Izzah: Jurnal Hasil-Hasil Penelitian, 1(1), 1-15.

Khusniyah, N., \& Hakim, L. (2019). Efektivitas Pembelajaran Berbasis Daring: Sebuah Bukti pada Pembelajaran Bahasa Inggris. Jurnal Tatsqif, 17(1), 19-33.

Kuntarto, E. (2017). Keefektifan Model Pembelajaran Daring dalam Perkuliahan Bahasa Indonesia di Perguruan Tinggi. Journal Indonesian Language Education and Literature, 3(1), 99-110.

Mustofa, M. I., Chodzirin, M., \& Sayekti, L. (2019). Formulasi Model Perkuliahan Daring Sebagai Upaya Menekan Disparitas Kualitas Perguruan Tinggi (Studi terhadap Website pditt.belajar.kemdikbud.go.id). Walisongo Journal of Information Technology, 1(2), 151160.

Novita, M. (2017). Sarana dan Prasarana yang Baik Menjadi Bagian Ujung Tombak Keberhasilan Lembaga Pendidikan Islam. Nur El-Islam, 4(2), 97-129.

Rusdiana, E., \& Nugroho, A. (2020). Respon pada Pembelajaran Daring bagi Mahasiswa Mata Kuliah Pengantar Hukum Indonesia. INTEGRALISTIK, 31(1),1-12

Sofyana, L., \& Rozaq, A. (2019). Pembelajaran Daring Kombinasi Berbasis Whatsapp pada Kelas Karyawan Prodi Teknik Informatika Universitas PGRI Madiun. Jurnal Nasional Pendidikan Teknik Informatika, 8(1), 81-86.

Suyanto \& Jihad, A. (2013). Menjadi Guru Profesional (Strategi Meningkatkan Kualifikasi dan Kualitas Guru di Era Global). Jakarta: Esensi Erlangga Group.

Tantri, N. R. (2018). Kehadiran Sosial dalam Pembelajaran Daring Berdasarkan Sudut Pandang Pembelajar Pendidikan Terbuka dan Jarak Jauh. Jurnal Pendidikan Terbuka dan Jarak Jauh, 19(1), 19-30 